\title{
Karstic groundwater origin and recharge process in Zagros region: insights from stable isotopes $\left(\delta^{18} \mathrm{O}\right.$ and $\left.\delta^{2} \mathrm{H}\right)$ approach
}

\author{
Mojtaba Heydarizad ${ }^{1}$ \\ 1-Geography department, Letters and Humanities faculty, Ferdowsi University of Mashhad, Mashhad, Iran \\ *Corresponding author email: heydarizad.moji@gmail.com \\ *Corresponding author telephone: +989366864942
}

\begin{abstract}
Zagros is an important region with high quality and quantity karstic water resources in the Middle East. This region provides a dominant part of potable and agricultural water needs for its inhabitants as well as agricultural water needs for nearby regions. Therefore, studying karstic water resources in Zagros by accurate methods such as stable isotopes techniques is very important. In this investigation, hydrological characteristics of groundwater resources including groundwater origin, recharge rate and recharge elevation have been studied using stable isotopes $\left({ }^{18} \mathrm{O}\right.$ and $\left.{ }^{2} \mathrm{H}\right)$. The results show that stable isotopes signatures in groundwater resources show notable variations across Zagros and groundwater resource mainly plot on south and west Zagros meteoric water lines. In addition, recharge elevation and recharge rate in groundwater resources also show significant variations in Zagros. Finally, the stable isotopes signatures in precipitation and groundwater has been used to study the role of each dominant air mass (contribution percentage of precipitation events originate from each air mass) in groundwater resources recharge using Simmr package in R language. Overall, groundwater resources in Zagros is recharged by precipitation events originate from various air masses and they have various recharge rates and recharge elevations.
\end{abstract}

Keywords: Groundwater, Stable isotopes, Zagros, Recharge rate, Recharge elevation, Simmr package 


\section{1-Introduction:}

During the recent decades, large population growth as well as long droughts cause extremely difficult situation mainly in arid and semi-arid regions across the world. High quality and quantity karstic groundwater resources play a crucial role in providing water needs for a large number of the world inhabitants. In Middle East countries, although energy resources are intensively available, but the water resources are in scarce. Zagros region with its high quality water resources has an important role to provide water needs for the large number of people in Middle East. Zagros is extending from the northeast Iraq and southeast Turkey to the strait of Hormoz in the Persian Gulf (Fig. 1).

The climate of Zagros shows large variations from semi-arid and arid climate in south parts to cold and humid in high elevations of west Zagros. Various moisture sources and air masses influence Zagros through the year (Heydarizad et al., 2019, 2018; Mohammadzadeh et al., 2020). In the west part of the Zagros region, the Mediterranean (MedT) air mass which transfers the moisture of the Mediterranean Sea is dominant. However in the southern part, the role of continental tropical (cT) air mass also known as Sudan air mass is significant beside the MedT air mass. In addition to cT and MedT air masses, maritime polar (mP) and continental polar (cP) air masses also influence Zagros region, but they have minor role (Heydarizad, 2018a; Mohebi, 2012). The precipitation amount also shows large variations in Zagros, as the precipitation amount rises to more than $800 \mathrm{~mm}$ in the western parts, while in southern part of the Zagros region near to the Persian Gulf coast, precipitation amount decreases to less than 150 mm per year (Ahmadi, 2013). As the moisture sources and air masses causing precipitation as well as precipitation amount vary dominantly across Zagros, this region has been classified to two parts (west Zagros and south Zagros). These variations have direct influence in groundwater recharge across this region.

Karstic-carbonate formations have large outcrops and cover about 55\% of the Zagros region (Raeisi, 2004). Kartsic aquifers exist in carbonate formations have high quality and quantity water resources which provide dominant part of water needs for a large number of Middle East inhabitants in Iran, Iraq and the southeast of Turkey.

The intense karstification caused by tectonic activity and high precipitation amount across Zagros provides the basic requirement for the occurrence of numerous karstic springs with high discharge rates 
across this area (Fig.2). Although the importance of the karstic water resources is obvious, there are a few numbers of the comprehensive studies on water resources (such as Mahmoudi savandi, 2008, 1995; Mahmoudi savandi et al., 2000; Niroomand and Pakzad, 1997; Rezaei et al., 1998) in Zagros. However, these investigations only consider small areas in Zagros and the lack of accurate and comprehensive study which covers all this region simultaneously exist.

The stable isotope techniques are among the most accurate and reliable methods to study water resources origin and evaluations (Clark and Fritz, 1997). Among the various stable isotopes, the ${ }^{18} \mathrm{O}$ and ${ }^{2} \mathrm{H}$ in water molecule have a great application in water resources studies since Harmon Craig ( 1961) has found that ${ }^{18} \mathrm{O} /{ }^{16} \mathrm{O}$ and ${ }^{2} \mathrm{H} / \mathrm{H}$ ratio have a strong correlation in fresh water resources. The stable isotopes $\left({ }^{18} \mathrm{O}\right.$ and ${ }^{2} \mathrm{H}$ ) have been used in numerous hydrological studies worldwide (such as Ali and Ajeena, 2016; Ali et al., 2015; Bagheri et al., 2019; Cerar et al., 2018; Chitsazan et al., 2015; Jassas and Merker, 2015; Jiang et al., 2019; Mohammadzadeh and Heydarizad, 2020; Parizi and Samani, 2014; Rafighdoust et al., 2015; Rezaei et al., 2013; Xu et al., 2018; Yeh et al., 2014) to investigate the groundwater origin, evaluation and groundwater/surface water interaction.

Although stable isotopes techniques are very accurate, but due to the scarcity of the required instruments for stable isotopes analyses as well as capable experts to prepare samples and run the instruments to analyze isotopes, stable isotopes analyses and data are not very common in developing and undeveloped countries.

In addition to sampling and analyses of stable isotope in enough stations in each study, developing the spatial distribution maps of stable isotopes $\left({ }^{18} \mathrm{O}\right.$ and $\left.{ }^{2} \mathrm{H}\right)$ is also very important. Developing stable isotopes distribution maps has numerous advantages such as such as providing data for the regions where sampling is not available (Such as very high mountainous regions). There are numerous methods such as Kriging, Spline, and Inverse Distance Weighting (IDW) to develop distribution maps.

Finally, the contribution percentage of each moisture source/air mass (precipitation events originate each air mass/moisture source) in karstic groundwater recharge can also be done using stable isotopes signatures in precipitation and karstic groundwater resources and mixing model "Simmr package" (Parnell et al., 2010) in R language (R Core Team, 2018). 
The aim of this paper is firstly to study the origin, recharge elevation and recharge rate of groundwater resources across Zagros using stable isotopes techniques. Secondly, developing the stable isotopes distribution maps in karstic groundwater across this region. Finally, the contribution percentage of each dominant air masses $\mathrm{cP}, \mathrm{cT}$, MedT and $\mathrm{mP}$ (precipitation events originating each dominant air mass) in the recharge of karstic groundwater resources in Zagros has also been studied.

\section{2-Material and Methods:}

Stable isotopes $\left({ }^{18} \mathrm{O}\right.$ and $\left.{ }^{2} \mathrm{H}\right)$ data in karstic groundwater resources across the Zagros (24 stations in Iran and 1 station in Iraq) were gathered from scientific papers, theses and reports of Iran regional water authorities. Each station is consisted of several karstic groundwater samples and the number of the studied groundwater samples for each station is presented in Table1. Stable isotopes $\left({ }^{18} \mathrm{O}\right.$ and $\left.{ }^{2} \mathrm{H}\right)$ data are presented in delta notation $(\delta \%)$ which is the relative deviation of the sample from the standard (Vienna Standard Mean Ocean Water (VSMOW)), via the equation (1):

$$
\delta 180 \text { sample }=\left(\frac{\left(\frac{180}{160}\right) \text { sample }}{\left(\frac{180}{160}\right) \text { reference }}-1\right) * 1000 \% \text { VSMOW }
$$

The water samples were analyzed for stable isotopes in different laboratories across the world including Stable Isotope Laboratory at the University of Waterloo, Canada; G.G. HATCH Stable Isotope Laboratory at the University of Ottawa, Canada; National Research Center for Environment and Health (GSF), Neuherberg, Germany; Federal Institute for Geosciences and Natural Resources in Hannover, Germany; and also several other laboratories across the world.

Furthermore, the karstic groundwater recharge rates in Zagros were calculated via Equations 2 and 3 (Allison et al., 1984).

$\delta^{2} \mathrm{H}$ shift $=22 / \sqrt{ }$ recharge $(\mathrm{mm} /$ year $)$

$\delta^{18} \mathrm{O}$ shift $=3 / \sqrt{ }$ recharge $(\mathrm{mm} /$ year $)$ 
In which the shifts represent the deviation of the water samples from the LMWL.

The recharge elevation has also been calculated for each karstic groundwater samples in the studied stations using west and south Zagros "elevation- $\delta 180$ in precipitation" correlations.

Furthermore, the spatial distribution maps of ${ }^{18} \mathrm{O}$ and ${ }^{2} \mathrm{H}$ in groundwater resources over the Zagros region has been developed using Kriging, Spline, and Inverse Distance Weighting (IDW), techniques by Q-Gis software-version Desktop 3.14.15 (QGIS Development Team, 2021). The accuracy of the developed maps has been validated using Root Mean Square Error (RMSE) which is calculated using the equation (4):

$$
\text { RMSE }=\sqrt{\frac{\sum_{i=1}^{N}(\text { predicted } \mathrm{i}-\text { Actual } \mathrm{i})^{\wedge} 2}{\mathrm{~N}}}
$$

Finally, the contribution percentage of each air mass (precipitation events originating from each dominant air mass) in karstic groundwater resources recharge in Zagros region was calculated. In the first step of this procedure, the average stable isotopes signatures in precipitation events originate from each air mass (cT, cP, MedT and mP) influence Zagros were used which has been obtained from previous studies (Heydarizad, 2018b) (Supplementary File 2).

Then, the contribution percentage of the precipitation events originating from each air mass in the recharge of the groundwater resources was calculated by the stable isotopes signatures in precipitation and groundwater resource using Simmr package scripts (Parnell et al., 2010) in R language (R Core Team, 2018) (Supplementary File-1). The Simmr package is developed, to solve mixing equations within a Bayesian framework. This package needs three input objects to run such as the mixtures (the surface water samples in which each air mass contribution is calculated), the endmember/source means, and the endmember/source standard deviation (SD) (Parnell and Inger, 2021).

\section{Results and discussion:}

The average $\delta^{18} \mathrm{O}$ and $\delta^{2} \mathrm{H}$ values in groundwater resources in 25 stations in Zagros are presented in (Supplementary File 3), while the spatial distribution of these stations across Zagros are shown in Figure 3. 
The stable isotopes distribution maps in groundwater have been developed using IDW, Kriging and Spline methods and the developed maps have been validated by calculating RMSE for each developed maps. The maps developed by IDW show the lowest RMSE values which confirms that the maps developed by this method has high accuracy (Table 1). Furthermore, the stable isotopes $\left({ }^{18} \mathrm{O}\right.$ and $\left.{ }^{2} \mathrm{H}\right)$ in maps developed by IDW show notable variations in Zagros (Fig.4 a\&b). The large variations observed in the stable isotopes signatures in karstic groundwater resources are due to various parameters which influence groundwater resources in this region. Therefore main hydrogeological characteristic of karstic groundwater resources (such as ground water origin, groundwater recharge rate and recharge elevation) as well as various precipitation moisture sources should be studied accurately.

\subsection{Studying the karstic groundwater origin in Zagros using stable isotopes techniques}

To study the groundwater origin, these resources plot on local meteoric water lines ( $L M W L ' s)$. Plotting groundwater resources in Zagros region on south Zagros meteoric water lines (SZMWL) and west Zagros meteoric water line (WZMWL) (Heydarizad et al., 2019) (Fig.5) indicate that Zagros groundwater resources dominantly plot on these lines. Groundwater resources also show negligible deviation from both SZMWL and WZMWL. This is due to very low evaporation during the infiltration process and quick recharge of precipitation to groundwater system in Zagros.

Karstic groundwater resources in the southern part of Zagros (such as Kangan, Ahram and Shapour stations) show more enriched isotope values compared to the stations located on the western part of this region (Fig. 5) and Table-1. This is due to higher air temperature and more intense evaporation influencing both precipitation and groundwater resources in the southern part compare to western part of Zagros.

\subsection{Studying average recharge elevation and recharge rate in groundwater resources in Zagros} region

The recharge process has an important influence on groundwater resources quality and quantity in karstic regions. In Zagros, the recharge elevation and recharge rate have also been studied by stable isotopes techniques. 
The average recharge elevation of groundwater resources was calculated using the elevation- $\delta^{18} \mathrm{O}$ in precipitation correlation in western (Elevation $=-65.78 \delta^{18} \mathrm{O}+1061.1, \mathrm{R}^{2}=0.33$ ) and southern (Elevation $=-211.95 \delta^{18} \mathrm{O}+660.89, \mathrm{R}^{2}=0.61$ ) parts of Zagros which shows $1.52 \%$ and $0.47 \%$ depletion in $\delta^{18} \mathrm{O}$ per $100 \mathrm{~m}$ elevation increase, respectively.

Calculating the recharge elevation in the studied stations in Zagros (Table. 2) shows that the higher recharge elevation of groundwater resources is observed in the western compare to the southern part of Zagros. However, in the southern part of the Zagros in the Bakhtegan station (Station number 18), groundwater resources show more depleted isotope values and higher recharge elevation compare to other stations in the southern part of Zagros. This is due to the fact that Bakhtegan station is located in high elevations of Zagros mountain range (called Trust Zagros) with cold and semi-arid climate (low annual air temperature). On the other hand, among the water resources in the west Zagros, the samples which have been taken from Pole Dokhtar (station number 11) station shows lower recharge elevation and also more enriched isotope values compare to other stations in this part of Zagros. The groundwater water resources in these stations mainly recharge from enriched precipitation events in the low elevation of west Zagros. However, the highest recharge elevation of groundwater resources in the west Zagros is observed in Orumieh-Oshnavieh (station number 3) in Iran. Groundwater resources in this station of west Zagros mainly recharge by precipitation in very high mountainous region.

In addition to recharge elevation, the groundwater recharge rate across the Zagros has also been estimated using the stable isotope technique and equations 2 and 3. The calculated recharge rate varies dominantly from 1 to $115 \mathrm{~mm}$ per year (Table 2). The higher recharge rate in some parts of Zagros such as Bakhtegan, Erbil, and Javanrud stations is due to active tectonics and the developed karstic features (Ghobadi et al., 2015) as well as high annual precipitation in these parts of Zagros (Mohebi, 2012) which facilitate precipitation infiltration to the karstic aquifers. However the very low recharge rate is observed in Bibi talkhoun, Keyno, Lorestan-Aleshtar, Alvand, and Kazerun stations. These low recharge rate is due to low annual precipitation in these part of Zagros (Mohebi, 2012). 


\subsection{Calculating the contribution rate of various air masses in groundwater recharge across the}

\section{Zagros region}

In addition to studying the recharge elevation and recharge rate in karstic groundwater resources in Zagros, the contribution percentage of each air mass (precipitation events originate each dominant air masses) in groundwater resources recharge has also been studied. To achieve this goal, firstly the average stable isotopes $\left({ }^{18} \mathrm{O}\right.$ and $\left.{ }^{2} \mathrm{H}\right)$ data in precipitation events originate from each main air masses influence Zagros (cT, cP, MedT and mP) have been obtained from Heydarizad (2018) (Supplementary File.2).

Considering the average ${ }^{18} \mathrm{O}$ and ${ }^{2} \mathrm{H}$ in precipitation events originate from each air mass as well as stable isotopes signatures in groundwater resources, the contribution percentage of each air mass in groundwater resources recharge has been determined using mixing model "Simmr package". The contribution of each air mass in groundwater recharge in 12 selected stations across the Zagros region (in some parts of the Zagros region where several stations exists in small area solely one station is selected) has been calculated (Table 3).

Assessment the role of each air mass in groundwater recharge show that the precipitation events which originate from the cT air mass has dominant role in the recharge of groundwater resources in all parts of the Zagros region. In the west part of the Zagros region in addition to the $\mathrm{cT}$ air mass, the role of the MedT air mass is also important in groundwater recharge. In higher latitudes in northwest part of the Zagros region in Orumieh-Oshnavieh, the role of precipitation events source from $\mathrm{mP}$ air mass is important in groundwater recharge. In the south part of Zagros, the same as the west part, the role of precipitation events originate $\mathrm{cT}$ air mass in the recharge of the groundwater is dominant in most stations, while precipitation events originate $\mathrm{cP}$ air mass and to lower extent MedT and $\mathrm{mP}$ air masses have minor role.

\section{Conclusion:}

Studying the stable isotopes $\left({ }^{18} \mathrm{O}\right.$ and $\left.{ }^{2} \mathrm{H}\right)$ in groundwater resources presents very valuable results regarding the karst groundwater hydrology in Zagros. Groundwater recharge elevation calculate by stable isotopes techniques show large variations across the Zagros region. The higher recharge elevation 
of karst groundwater resources is usually observed in the stations in west part compare to the stations in the south part of Zagros. Groundwater recharge rate has also been calculated in karst groundwater resources in Zagros. In some parts of the Zagros region, the higher recharge rate is due to active tectonics and the developed karstic features which facilities precipitation infiltration to the karstic aquifers. In addition, various air masses and precipitation moisture sources influence groundwater resources in Zagros. Studying the contribution percentage of each air mass (precipitation events originate each air mass) in groundwater recharge using mixing model "Simmr-Package" shows that cT air mass has dominant role in groundwater recharge in all parts of Zagros. However in west and northwest part of Zagros, the role of MedT and $\mathrm{mP}$ air masses is also important in the recharge of groundwater resources.

Acknowledgements:

Our special thanks to our colleagues at Ferdowsi University of Mashhad and Shiraz University for their help and support during this study.

Funding:

This study did not receive any grant from funding organizations in the public, commercial, or not-forprofit sectors.

\section{References}

Ahmadi, J., 2013. Precipitation variations over Zagros region. Water Sci. 18, 23-29.

Aldega, L., Corrado, S., Carminati, E., Shaban, A., Sherkati, S., 2014. Thermal evolution of the Kuhe-Asmari and Sim anticlines in the Zagros fold-and-thrust belt: Implications for hydrocarbon generation. Mar. Pet. Geol. 57, 1-13. https://doi.org/https://doi.org/10.1016/j.marpetgeo.2014.04.017

Ali, K., Ajeena, R., 2016. Assessment of interconnection between surface water and groundwater in Sawa Lake area, southern Iraq, using stable isotope technique. Arab. J. Geosci. 9. https://doi.org/10.1007/s12517-016-2673-6

Ali, K.K., Al-Kubaisi, Q.Y., Al-Paruany, K.B., 2015. Isotopic study of water resources in a semi-arid 
region, western Iraq. Environ. Earth Sci. 74, 1671-1686. https://doi.org/10.1007/s12665-015$4172-6$

Allison, G.B., Barnes, C.J., Hughes, M.W., Leaney, F.W.J., 1984. Effects of climate and vegetation on Oxygen-18 and deuterium profiles in soils., in: Isot. Hydrol. IAEA. Vienna, Austria, pp. 105122.

Bagheri, R., Nosrati, A., Jafari, H., Eggenkamp, H.G.M., Mozafari, M., 2019. Overexploitation hazards and salinization risks in crucial declining aquifers, chemo-isotopic approaches. J. Hazard. Mater. 369, 150-163. https://doi.org/https://doi.org/10.1016/j.jhazmat.2019.02.024

Cerar, S., Mezga, K., Žibret, G., Urbanc, J., Komac, M., 2018. Comparison of prediction methods for oxygen-18 isotope composition in shallow groundwater. Sci. Total Environ. 631-632, 358-368. https://doi.org/https://doi.org/10.1016/j.scitotenv.2018.03.033

Chitsazan, M., Karimi Vardanjani, H., Karimi, H., Charchi, A., 2015. A comparison between karst development in two main zones of Iran: case study---Keyno anticline (Zagros Range) and Shotori anticline (Central Iran). Arab. J. Geosci. 8, 10833-10844. https://doi.org/10.1007/s12517-015-1961-x

Clark, I.D. (Ian D., Fritz, P. (Peter), 1997. Environmental isotopes in hydrogeology. CRC Press/Lewis Publishers.

Criag, H., 1961. Isotopic Variations in Meteoric Waters. Science (80-. ). 133, 1702-3. https://doi.org/10.1126/science.133.3465.1702

Ghanadian, M., Faghih, A., Abdollahie Fard, I., Kusky, T., Maleki, M., 2017. On the role of incompetent strata in the structural evolution of the Zagros Fold-Thrust Belt, Dezful Embayment, Iran. Mar. Pet. Geol. 81, 320-333. https://doi.org/https://doi.org/10.1016/j.marpetgeo.2017.01.010

Ghobadi, M.H., Torabi-Kaveh, M., Miri, M., Mahadiabadi, M., 2015. An introduction to the karst geomorphology of the Bisetun-Taqe Bostan historical region (northeast Kermanshah, Iran) with special emphasis on karst development as a serious threat for the UNESCO World Heritage Site. Bull Eng Geol Env. 74, 1071-1086. https://doi.org/10.1007/s10064-014-0662-0

Heydarizad, M., 2018a. Meteoric water lines of Iran for various precipitation sources. Shiraz 
University, Iran.

Heydarizad, M., 2018b. Hydro chemical charcterstic of inland rivers in Khorasan Razavi province, North-Eastern Iran. Int.J. Water xx, xx-xx.

Heydarizad, M., Raeisi, E., Sorí, R., Gimeno, L., 2019. Developing Meteoric Water Lines for Iran Based on Air Masses and Moisture Sources. Water 11, 2359.

Heydarizad, M., Raeisi, E., Sori, R., Gimeno, L., Nieto, R., Heydarizad, M., Raeisi, E., Sori, R., Gimeno, L., Nieto, R., 2018. The Role of Moisture Sources and Climatic Teleconnections in Northeastern and South-Central Iran's Hydro-Climatology. Water 10, 1550. https://doi.org/10.3390/w10111550

Jassas, H.A., Merker, B.J., 2015. Investigating groundwater recharge by means of stable isotopes in the Al-Khazir Gomal Basin, northern Iraq. Env. Earth Sci 73, 8533-8546. https://doi.org/https://doi.org/10.1007/s12665-015-4013-7

Jiang, Z., Xu, T., Mallants, D., Tian, H., Owen, D.D.R., 2019. Numerical modelling of stable isotope ( $2 \mathrm{H}$ and $18 \mathrm{O})$ transport in a hydro-geothermal system: Model development and implementation to the Guide Basin, China. J. Hydrol. 569, 93-105. https://doi.org/https://doi.org/10.1016/j.jhydrol.2018.11.065

Mahmoudi savandi, S., 2008. Tracers studies to determine vulnerable area in Dashtak anticline Kazeroun. Shiraz, Iran.

Mahmoudi savandi, S., 1995. hydrogeology of Mahrloo karstic zones. Shiraz, Iran.

Mahmoudi savandi, S., Karimi, H., Jokar, B., 2000. Semi detail studies in Orumieh-Oshnavieh kartic region. Shiraz, Iran.

Mohammadzadeh, H., Heydarizad, M., 2020. A conceptual model for water resources circulation patterns in Andarokh-Kardeh region (NE, Iran). Geochemistry 125593. https://doi.org/https://doi.org/10.1016/j.chemer.2019.125593

Mohammadzadeh, H., Mayvan, J.E., Heydarizad, M., 2020. The effects of moisture sources and local parameters on the $18 \mathrm{O}$ and $2 \mathrm{H}$ contents of precipitation in the west of Iran and the east of Iraq. Tellus B Chem. Phys. Meteorol. 72, 1-15. https://doi.org/10.1080/16000889.2020.1721224 Mohebi, A., 2012. Studying the parameters influenceing precipitation variations across Middle East. 
Water Resour. 15, 205-209.

Niroomand, M.H., Pakzad, M., 1997. studies of Bakhtegan karstic water resources.

Parizi, H.S., Samani, N., 2014. Environmental Isotope Investigation of Groundwater in the Sarcheshmeh Copper Mine Area, Iran. Mine Water Environ. 33, 97-109. https://doi.org/10.1007/s10230-014-0277-5

Parnell, A., Inger, R., 2021. Stable Isotope Mixing Models in R with simmr [WWW Document]. URL https://cran.r-project.org/web/packages/simmr/vignettes/simmr.html

Parnell, A., Inger, R., Bearhop, S., L Jackson, A., 2010. Source partitioning using stable isotopes: coping with too much variation. PLoS One 5, 5.

QGIS Development Team, 2021. QGIS Geographic Information System.

Raeisi, E., 2004. Iran cave and karst. Encycl. ofCave Karst.

Rafighdoust, Y., Eckstein, Y., Harami, R.M., Gharaie, M.H.M., Griffith, E.M., Mahboubi, A., 2015. Isotopic analysis, hydrogeochemistry and geothermometry of Tang-Bijar oilfield springs, Zagros region, Iran. Geothermics 55, 24-30.

https://doi.org/https://doi.org/10.1016/j.geothermics.2015.01.001

Rezaei, A., Zare, M., Raeisi, E., Ghanbari, R.N., 2013. Interaction of a Fresh Water Lake and a Karstic Spring via a Syncline Fold. Groundwater 51, 305-312. https://doi.org/10.1111/j.17456584.2012.00977.x

Rezaei, M., Krimi, H., Jokar, B., 1998. Semi detail studies of kazeroun and Persian Gulf karstic mega basin. Shiraz, Iran.

Team, R.C., 2018. R: A language and environment for statistical computing.

Xu, N., Gong, J., Yang, G., 2018. Using environmental isotopes along with major hydro-geochemical compositions to assess deep groundwater formation and evolution in eastern coastal China. J. Contam. Hydrol. 208, 1-9. https://doi.org/https://doi.org/10.1016/j.jconhyd.2017.11.003

Yeh, H.., Lin, H.., Lee, C.-H., Hsu, K.-C., Wu, C.-S., 2014. Identifying Seasonal Groundwater Recharge Using Environmental Stable Isotopes. Water 6. 
Table 1. RMSE values in the developed stable isotopes distribution maps in groundwater resources across Zagros.

\begin{tabular}{ccc}
\hline Map-Type & $\delta^{18} \mathrm{O}(\%)$ & $\delta^{2} \mathrm{H}(\% 0)$ \\
\hline IDW & 2.1 & 20.1 \\
Spline & 8.5 & 34.3 \\
Kriging & 7.9 & 31.3 \\
\hline
\end{tabular}

Table.2. The groundwater recharge elevation and recharge rate in the studied stations in Zagros.

\begin{tabular}{|c|c|c|c|c|c|c|}
\hline & Station & Zone & $\mathrm{N}$ & $\mathrm{E}$ & Elevation & Recharge rate \\
\hline 1 & Bibi talkhoun & SZ & 32.07 & 49.61 & 1763 & 1.1 \\
\hline 2 & keyno & SZ & 32.58 & 49.51 & 1886 & 0.8 \\
\hline 3 & Orumieh-Oshnavieh & WZ & 37.03 & 45.09 & 2723 & 4.4 \\
\hline 4 & Kangan & SZ & 27.83 & 52.06 & 1481 & 2.3 \\
\hline 5 & bushehr-Ahram & SZ & 28.88 & 51.27 & 1386 & 3.9 \\
\hline 6 & Hormozgan & SZ & 28.30 & 55.90 & 1615 & 11.1 \\
\hline 7 & Ilam-dare shahr & WZ & 33.13 & 47.37 & 1892 & 0.3 \\
\hline 8 & Tang bijar & WZ & 33.69 & 45.87 & 1630 & 3.2 \\
\hline 9 & Lorestan-Aleshtar & WZ & 33.86 & 48.26 & 2202 & 1.5 \\
\hline 10 & Havsan & WZ & 34.54 & 45.76 & 1719 & 9.8 \\
\hline 11 & Poleh Dokhtar & WZ & 33.15 & 47.71 & 1409 & 5.7 \\
\hline 12 & Alvand & WZ & 34.51 & 45.57 & 2015 & 1.0 \\
\hline 13 & Maharloo & SZ & 29.46 & 52.80 & 1916 & 3.0 \\
\hline 14 & Darab & SZ & 28.75 & 54.54 & 1716 & 4.7 \\
\hline 15 & Bushehr(Shahpor) & SZ & 29.47 & 51.14 & 1375 & 4.2 \\
\hline 16 & Kazerun & SZ & 29.61 & 51.65 & 1585 & 1.5 \\
\hline 17 & Arjan & SZ & 29.66 & 51.98 & 1568 & 8.6 \\
\hline 18 & Bakhtegan & SZ & 29.36 & 53.83 & 1994 & 107.0 \\
\hline 19 & Khersan dam & WZ & 31.24 & 50.97 & 1983 & 77.8 \\
\hline 20 & Erbil-Iraq & WZ & 36.27 & 44.07 & 2128 & 114.8 \\
\hline
\end{tabular}




\begin{tabular}{ccccccc}
21 & Sarpol Zahab & WZ & 34.46 & 45.86 & 1924 & 2.4 \\
22 & Ravansar & WZ & 34.71 & 46.65 & 2111 & 77.8 \\
23 & Paveh & WZ & 35.04 & 46.35 & 2147 & 19.5 \\
24 & Javanrud & WZ & 34.80 & 46.48 & 2189 & 100.0 \\
25 & Behbahan & SZ & 30.59 & 50.24 & 1784 & 10.5 \\
\hline
\end{tabular}

SZ stands for south Zagros

WZ stands for west Zagros 
Table 3. The contribution percentage of each dominant air mass in groundwater recharge across Zagros region.

\begin{tabular}{ccccc}
\hline Air mass & & & & \\
\hline Crumieh & 25.4 & 29.1 & 30.8 & 14.6 \\
Keyno & 11.2 & 35.5 & 19.2 & 34.2 \\
Kangan & 28.6 & 25.7 & 22.2 & 23.4 \\
Horomozgan & 27.3 & 37.2 & 16.3 & 19.6 \\
Tang Bijar & 22.5 & 33.0 & 21.1 & 23.4 \\
Aleshtar & 8.8 & 29.6 & 31.6 & 30.0 \\
Kerend & 13.2 & 38.6 & 23.6 & 24.6 \\
Arjan & 28.2 & 30.1 & 17.9 & 23.9 \\
Kersan dam site & 10.0 & 39.0 & 20.7 & 30.2 \\
Paveh & 8.0 & 35.7 & 30.0 & 26.1 \\
Dereh shahr & 14.9 & 38.3 & 15.2 & 31.6 \\
Bakhtegan & 36.3 & 25.3 & 21.9 & 16.5 \\
\hline
\end{tabular}




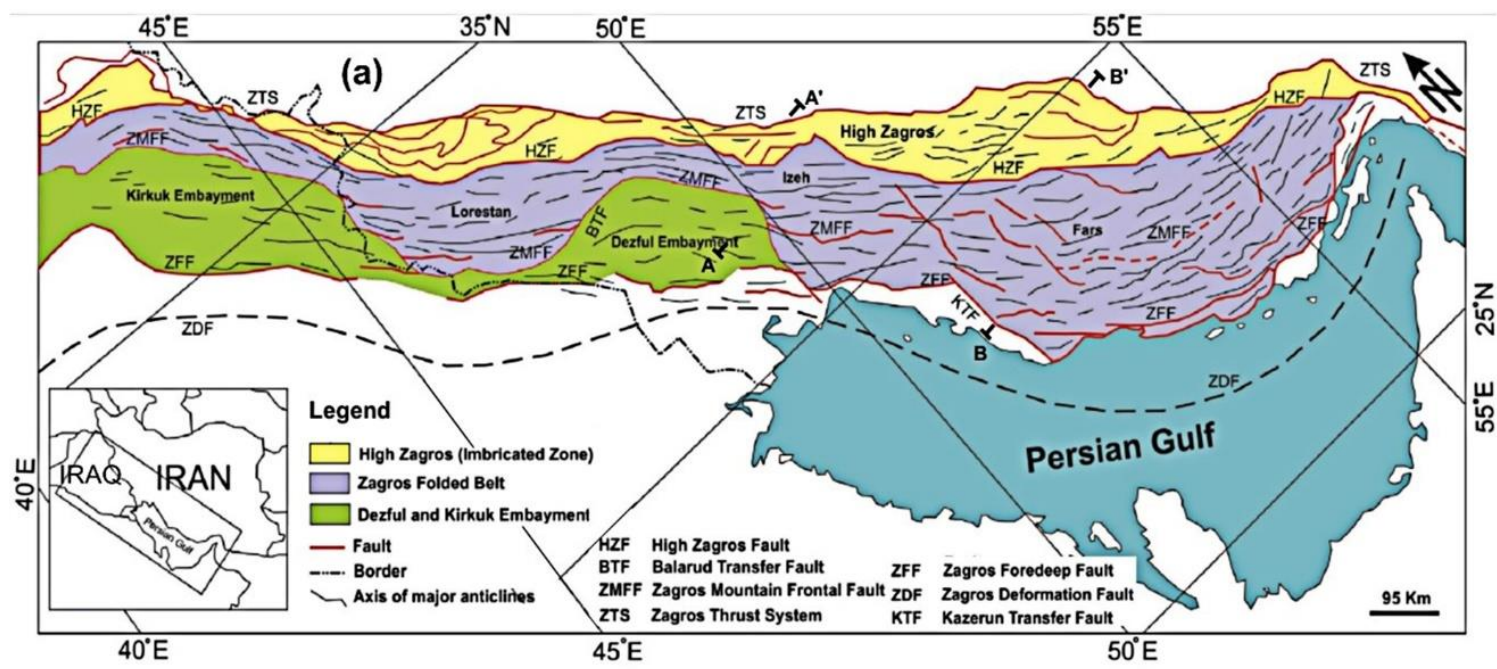

Legend

(b)

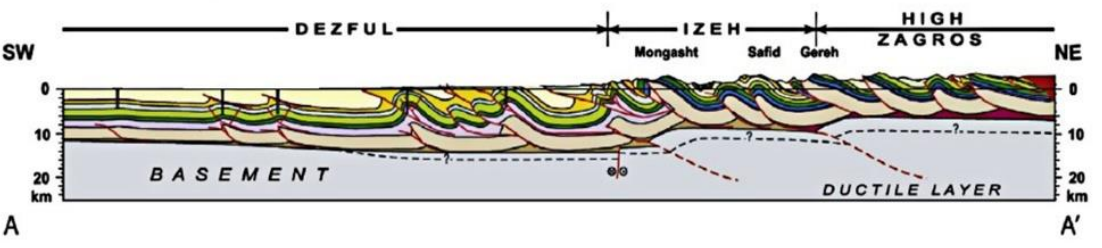

Mishan, Agha jari, Bakhtyari fms. MIDDLE MIOCENE : salt and evaporite (Gachsaran fm.)

Pabdeh, Gurpi, Asmari fms.

a : Kazhdumi Sarvak fms.

b: Sarvak fm.

A

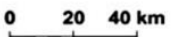

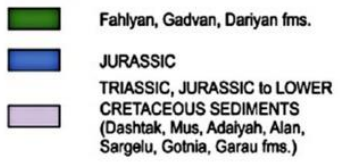

$\square$ TRIASSIC

$\square$ PALEOZOIC

$\square$ LOWER PALEOZOIC : shale or evaporite

LATE PROTEROZOIC - LOWER PALEOZOIC (Hormuz salt)

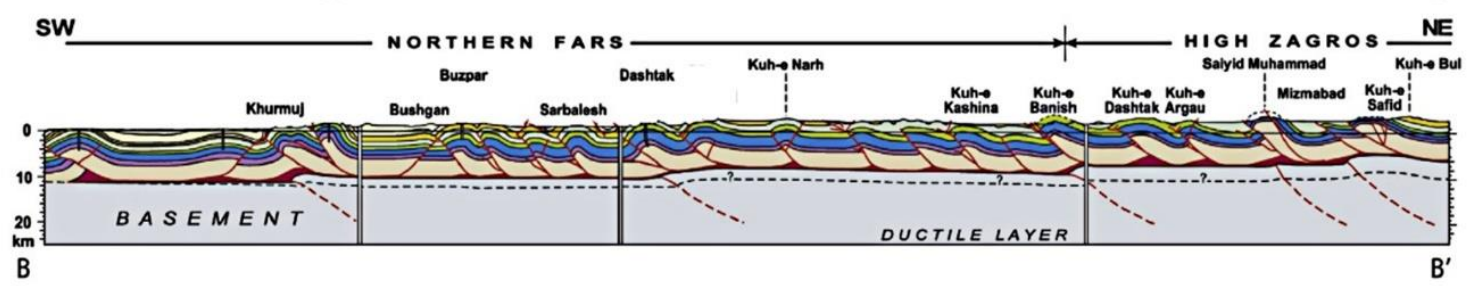

Fig-1. (a) Zagros location in Iran, Iraq and Turkey in Middle East (After: Ghanadian et al., 2017), (b) geological cross section in two locations A-A' and B-B' across Zagros (After: Aldega et al., 2014). 

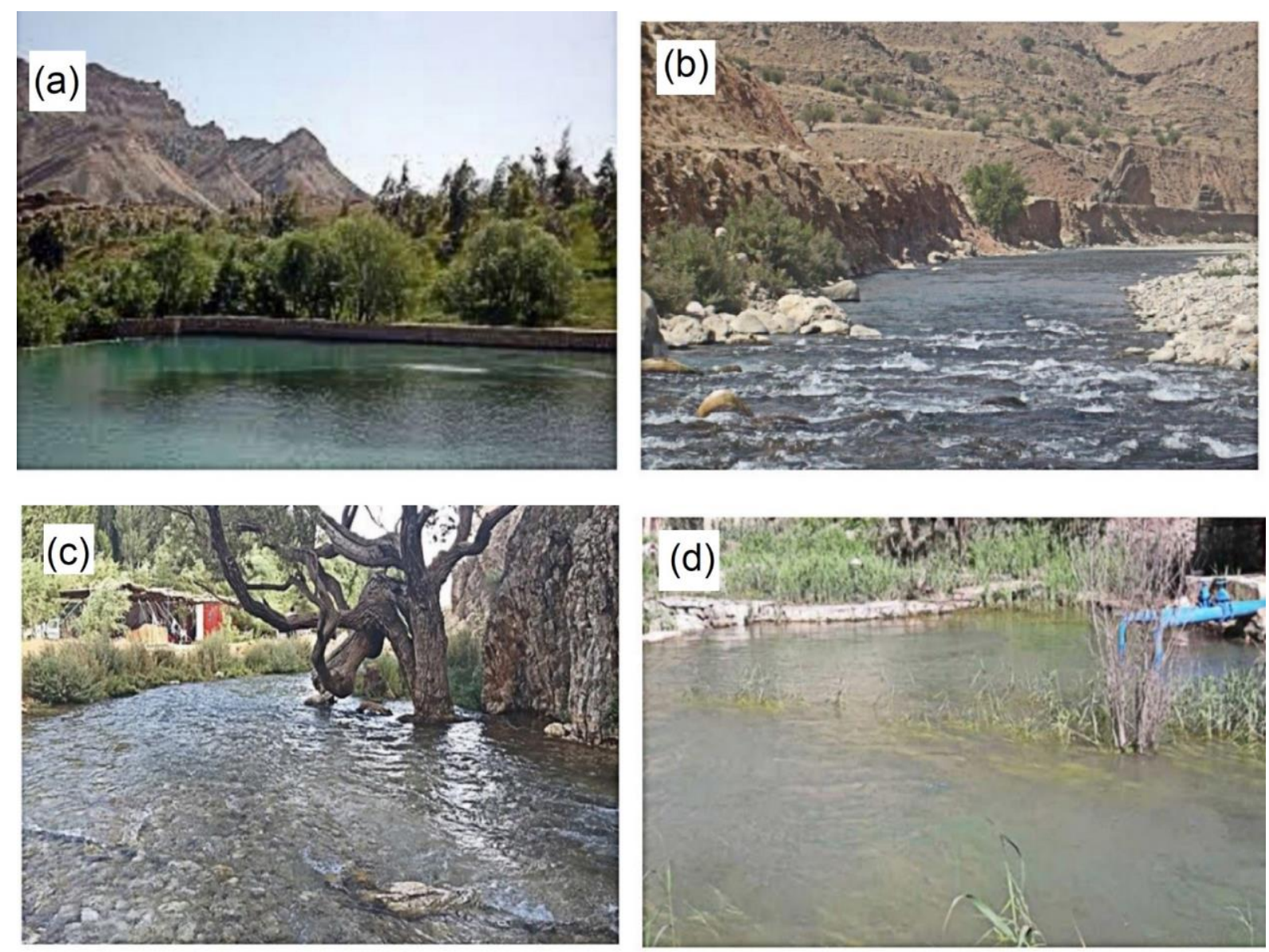

Fig-2. Karstic springs across Zagros region. (a) Sarab Dareh Shahr (station 7), (b) Soosan (station 2),

(c) Sheshpir (station 17), and (d) Sasan (station 16) karstic springs. (Note: sample IDs (numbers) refer to Supplementary File-3). 


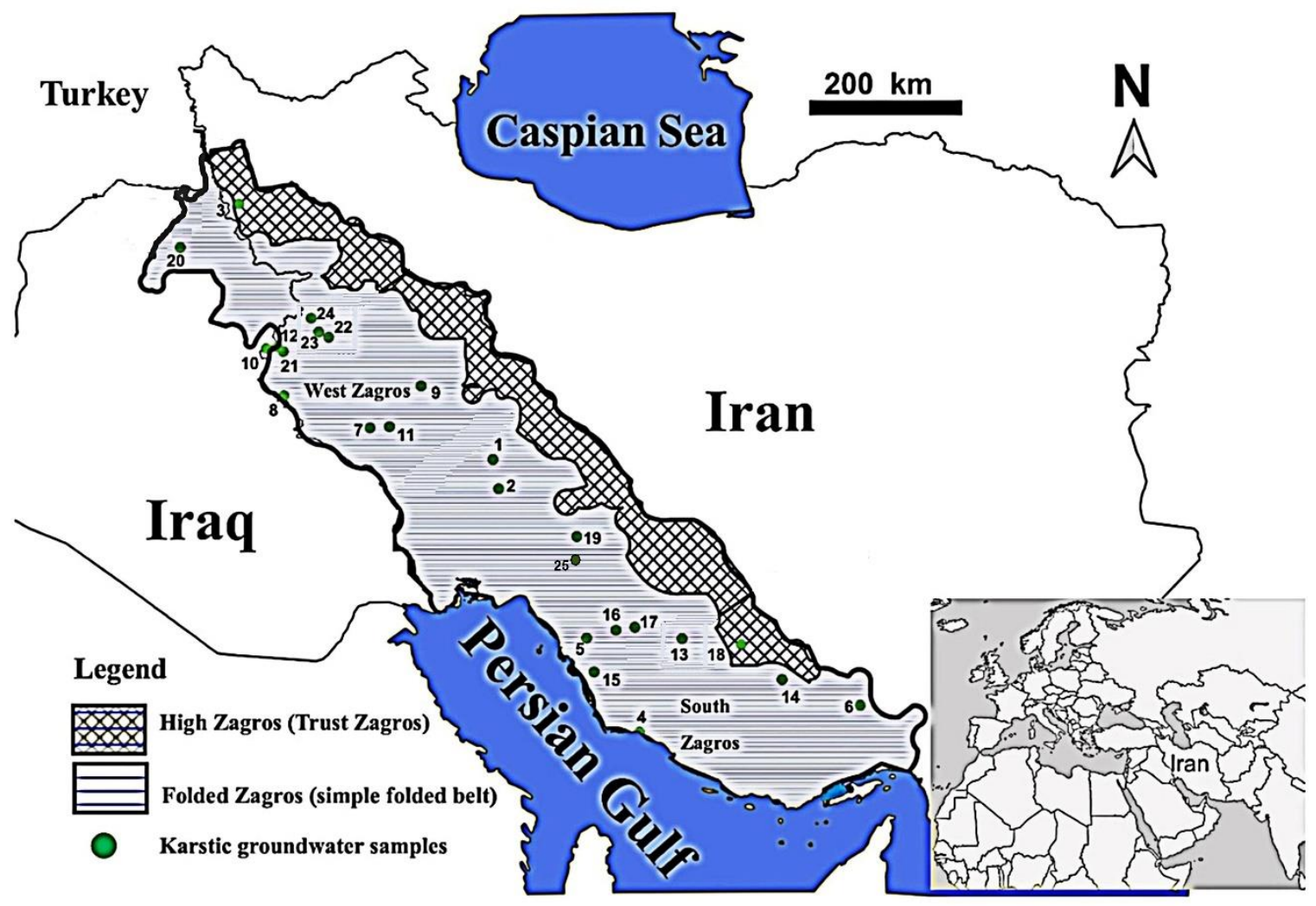

Fig-3. Karstic groundwater sampling locations across Zagros region. (Note: sample IDs (numbers) refer to Supplementary File-3). 

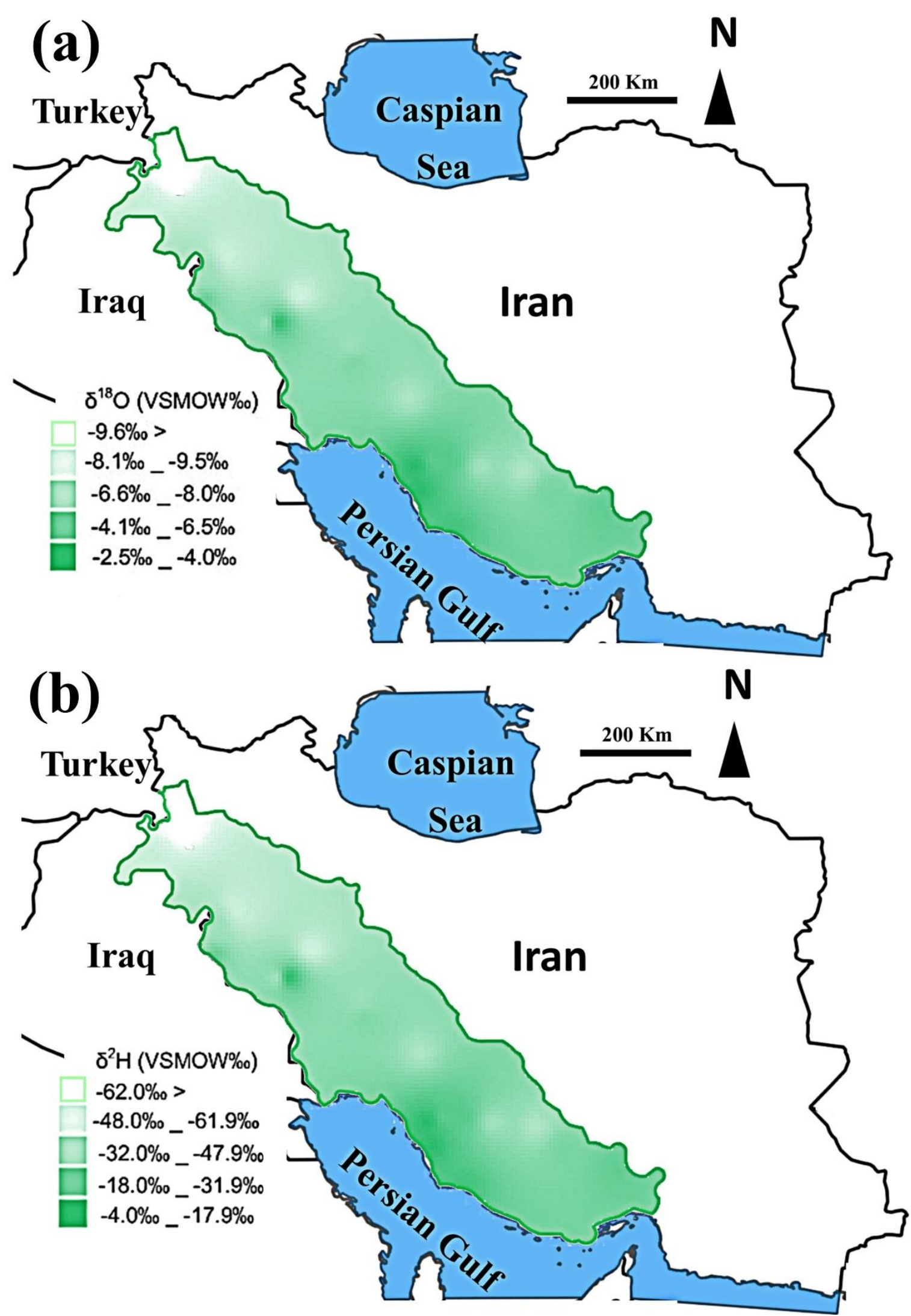

Fig-4. The spatial variations of groundwater $\delta^{18} \mathrm{O}(\mathrm{a})$ and $\delta^{2} \mathrm{H}(\mathrm{b})$ values across the Zagros region (maps have been developed using IDW technique). 

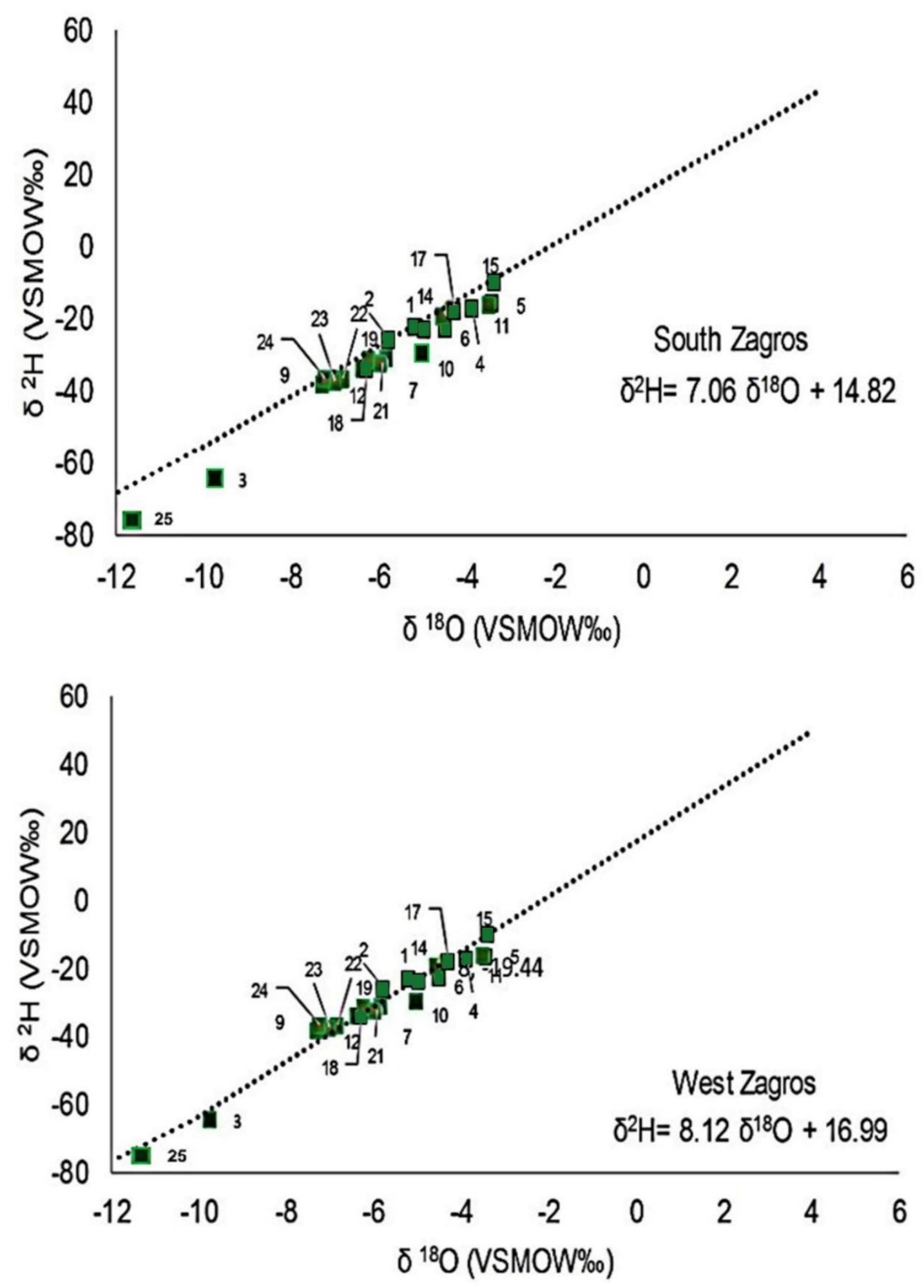

Fig-5. Plotting Zagros region's groundwater samples on the west and south Zagros meteoric water Lines (Heydarizad et al., 2019). (Note: sample IDs (numbers) refer to Supplementary File-3). 